\title{
Implementasi Kebijakan Program Pemberdayaan Ekonomi Masyarakat Petani Rumput Laut Desa Labuhan Kertasari Kabupaten Sumbawa Barat
}

\author{
Zulkifli Muhadli \\ Universitas Cordova, Indonesia \\ Correspondence email: drzulkiflimuhadli@gmail.com
}

\begin{abstract}
Abstrak. Adanya Program Pemberdayaan Ekonomi Masyarakat Petani Rumput Laut di Desa Labuhan Kertasari Kabupaten Sumbawa Barat dilatarbelakangi oleh sumberdaya yang mumpuni untuk melakukan pembudidayaan rumput laut dalam rangka meningkatkan perekonomian masyarakat di daerah tersebut. Dinas Kelautan dan Perikanan Kabupaten Sumbawa berupaya untuk meningkatkan perekonomi masyarakat petani rumput laut dengan menggali dan memberdayakan potensi yang dimiliki Desa Labuhan Kertasari tersebut. Tujuan dari penelitian ini adalah untuk mengetahui implementasi kebijakan program pemberdayaan ekonomi masyarakat pesisir terutama masyarakat petani rumput laut di Desa Labuhan Kertasari Kabupaten Sumbawa Barat. Implementasi kebijakan program tersebut berupa kebijakan dalam berkomuniasi antara pihak terkait dengan pemangku kebijakan, sumberdaya, disposisi atau sikap yang terlihat dari pembuat kebijakan dan struktur birokrasi yang diterapkan oleh daerah setempat. Tujuan dari program ini dapat tercapai jika Implementasi Pemberdayaan Ekonomi Masyarakat Petani Rumput Laut dilihat dari ketepatan kebijakan, ketepatan pelaksanaan, ketepatan lingkungan, ketepata target, dan ketepatan proses. Analisis data dilakukan secara kualitatif baik data primer maupun data sekunder, dengan tiga alur kegiatan (triangulasi) yaitu: reduksi data, penyajian data, verivikasi atau penyimpulan data. Hasil dari penelitian ini menunjukkan bahwa Dinas Kelautan dan Perikanan Kabupaten Sumbawa Barat telah siap melaksanakan Program Pemberdayaan Ekonomi Masyarakat Petani Rumput Laut di Desa Labuhan Kertasari. Implementasi Pemberdayaan Ekonomi Masyarakat Petani Rumput Laut sudah dilaksanakan dengan baik. Faktor- faktor yang mempengaruhi adalah (1) kemampuan pelaksana yang baik dalam menetapkan kebijakan walaupun ada kendala komunikasi antara para petani dengan pemerintah setempat, (2) kejelasan informasi yang diperoleh masyarakat, (3) komitmen pelaksana yang baik dalam melaksanakan program pemberdayaan ekonomi masyarakat tersebut, (4) pemanfaatan wewenang yang dimiliki pelaksana secara maksimal untuk menentukan target dan proses yang tepat.
\end{abstract}

Kata Kunci: Pemberdayaan; implementasi

Abstract. The existence of the Seaweed Farming Community Economic Empowerment Program in Labuhan Kertasari Village, West Sumbawa Regency is motivated by qualified resources to cultivate seaweed in order to improve the economy of the community in the area. The Department of Maritime Affairs and Fisheries of West Sumbawa Regency strives to improve the economy of the seaweed farming community by exploring and empowering the potential of Labuhan Kertasari Village. The purpose of this study was to determine the implementation of policies on economic empowerment programs for coastal communities, especially seaweed farming communities in Labuhan Kertasari Village, West Sumbawa Regency. The program's policy implementation is in the form of policies in communicating between related parties and policy makers, resources, dispositions or attitudes as seen by policy makers and the bureaucratic structure applied by the local area. The objective of this program can be achieved if the implementation of the Economic Empowerment of the Seaweed Farming Community is seen from the accuracy of policies, accuracy of implementation, accuracy of the environment, accuracy of targets, and accuracy of processes. Data analysis was carried out qualitatively, both primary and secondary data, with three activities (triangulation), namely: data reduction, data presentation, verification or data conclusion. The results of this study indicate that the Department of Marine Affairs and Fisheries of West Sumbawa Regency is ready to implement the Economic Empowerment Program for the Seaweed Farming Community in Labuhan Kertasari Village. The implementation of the Economic Empowerment of the Seaweed Farming Community has been carried out well. The influencing factors are (1) the ability of a good implementer in determining policies even though there are communication obstacles between farmers and local governments, (2) clarity of information obtained by the community, (3) commitment of good implementers in implementing the community economic empowerment program. , (4) maximizing the utilization of the executor's authority to determine appropriate targets and processes.

Keywords: empowerment; implementation

\section{PENDAHULUAN}

Pemerintah Indonesia telah berusaha melakukan penanggulangan kemiskinan semenjak tahun 1998 hingga saat ini. Salah satu upaya yang dilakukan oleh pemerintah berdasarkan Peraturan Mentri Kelautan dan Perikanan Republik Indonesia nomor 40/Permen$\mathrm{KP} / 2014$ tentang peran serta dan pemberdayaan masyarakat dalam pengeloaan wilayah pesisir dan pulaupulau kecil yaitu membuat strategi dan program dalam menanggulangi kemiskinan tersebut melalui Tim Nasional Percepatan Penanggulangan Kemiskinan (TNP2K), dimana ada empat strategi dasar yang telah ditetapkan dalam melakukan percepatan penanggulangan kemiskinan, yaitu: 1) menyempurnakan program 
perlindungan social, 2) peningkatan akses masyarakat miskin terhadap pelayanan dasar, 3) pemberdayaan masyarakat, dan 4) pembangunan yang inklusif. Terkait dengan strategi tersebut, pemerintah telah menetapkan instrumen penanggulangan kemiskinan yang dibagi berdasarkan tiga klaster, masing-masing antara lain sebagai berikut:

1) Klaster I merupakan suatu program bantuan sosial terpadu berbasis keluarga. Salah satunya adalah kelompok program penanggulangan kemiskinan berbasis bantuan dan perlindungan sosial yang bertujuan untuk melakukan pemenuhan hak dasar, pengurangan beban hidup, serta perbaikan kualitas hidup masyarakat miskin. Fokus pemenuhan hak dasar ditujukan untuk memperbaiki kualitas kehidupan masyarakat miskin untuk kehidupan lebih baik, seperti pemenuhan hak atas pangan, pelayanan kesehatan, dan pendidikan.

2) Klaster II merupakan program penanggulangan kemiskinan berbasis pemberdayaan masyarakat. Adapun upaya penanggulangan kemiskinan tidak cukup hanya dengan memberikan bantuan secara langsung pada masyarakat miskin karena penyebab kemiskinan tidak hanya disebabkan oleh aspek-aspek yang bersifat materialistik semata, akan tetapi juga karena kerentanan dan minimnya akses untuk memperbaiki kualitas hidup masyarakat miskin. Pendekatan pemberdayaan dimaksudkan agar masyarakat miskin dapat keluar dari kemiskinan dengan menggunakan potensi dan sumberdaya yang dimilikinya. Kelompok program penanggulangan kemiskinan berbasis pemberdayaan masyarakat merupakan sebuah tahap lanjut dalam proses penanggulangan kemiskinan. Pada tahap ini, masyarakat miskin mulai menyadari kemampuan dan potensi yang dimilikinya untuk keluar dari kemiskinan. Pendekatan pemberdayaan sebagai instrumen dari program ini dimaksudkan tidak hanya melakukan penyadaran terhadap masyarakat miskintentang potensi dan sumberdaya yang dimiliki, akan tetapi juga mendorong masyarakat miskin untuk berpartisipasi dalam skala yang lebih luas terutama dalam proses pembangunan di daerah.

3) Klaster III merupakan penanggulangan kemiskinan berbasis pemberdayaan usaha ekonomi mikro dan kecil. Program penanggulangan kemiskinan berbasis pemberdayaan usaha mikro dan kecil adalah program yang bertujuan untuk memberikan akses dan penguatan ekonomi bagi pelaku usaha berskala mikro dan kecil. Aspek penting dalam penguatan adalah memberikan akses seluas-luasnya kepada masyarakat miskin untuk dapat berusaha dan meningkatkan kualitas hidupnya.

Tiga Strategi penanggulangan kemiskinan sebagaimana ditunjukkan pada instrument klaster di atas menunjukkan bahwa upaya penanggulangan kemiskinan perlu bertumpu kepada upaya memberdayakan masyarakat. Secara konseptual, menurut Suharto (2005) bahwa pemberdayaan atau pemberkuasaan (empowerment, berasal dari kata "Power" (kekuasaan atau keberdayaan), pemberdayaan menunjuk pada kemampuan orang, khususnya selompok rentan dan lemah, sehingga mereka memiliki kekuatan atau kemampuan dalam memenuhi kebutuhan dasarnya, memiliki kebebasan, dan menjangkau sumber-sumber produktif yang memungkinkan mereka dapat meningkatkan pendapatannya serta memperoleh barangbarang dan jasa yang mereka perlukan. Jadi memberdayakan masyarakat dalam penanggulangan kemiskinan agar masyarakat memiliki daya dan kemampuan untuk terlibat aktif dan pada akhirnya dapat menentukan sendiri kehidupannya dengan memanfaatkan program-program yang dikelola oleh pemerintah.

Pada dasarnya, pemberdayaan menurut Sipahelut (2010) diletakkan pada kekuatan tingkat individu dan sosial. Sedangkan menurut Suharto (2010) mengungkapkan beberapa definisi pembaedayaan dilihat dari berikut ini:

1) Pemberdayaan dilihat dari tujuan adalah untuk meningkatkan kekuasaan orang-orang yang lemah atau tidak beruntung

2) Pemberdayaan sebagai proses adalah dengan mana orang menjadi cukup kuat untuk berpartisipasi dalam, berbagi pengontrolan atas, dan mempengaruhi terhadap, kejadian- kejadian serta lembaga-lembaga yang mempengaruhi kehidupannya. Pemberdayaan menekankan bahwa orang memperoleh keterampilan, pengetahuan, dan kekuasaan yang cukup untuk mempengaruhi kehidupannya dan kehidupan orang lain yang menjadi perhatiannya.

3) Pemberdayaan menunjuk pada usaha pengalokasian kembali kekuasaan melalui pengubahan struktur sosial.

4) Pemberdayaan dilihat dari cara-cara pemberdayaan adalah suatu cara dengan mana rakyat, organisasi, dan komunitas diarahkan agar mampu menguasai (berkuasa atas) kehidupannya.

Pemberdayaan masyarakat pada dasar-nya merupakan strategi perubahan sosial secara terencana yang ditujukan untuk mengatasi masalah atau memenuhi kebutuhan masyarakat. Dalam proses pemberdayaan, masyarakat mendapatkan pembelajaran agar dapat secara mandiri melakukan upaya-upaya perbaikan kualitas kehidupannya. Dengan demikian, proses tersebut harus dilaksanakan dengan adanya keterlibatan penuh masyarakat itu sendiri secara bertahap, berkesinambungan, dan berkelanjutan. Pemberdayaan masyarakat seringkali dilakukan pada masyarakat pedesaan untuk mewujudkan masyarakat desa dengan mapan ekonomi dimana pemberdayaan masyarakat desa dapat dilakukan melalui beberapa pendekatan yang salah 
satunya adalah pendekatan bottom-up dan top down. Menurut Shucksmith (2013) mengungkapkan tentang pendekatan bottom-up adalah untuk pembangunan pedesaan (didorong dari dalam, atau endogen) berdasarkan pada asumsi bahwa sumber daya spesifik daerah seperti alam, manusia dan budaya memegang kunci untuk perkembangannya. Sedangkan pembangunan pedesaan top-down melihat tantangan utamanya sebagai mengatasi perbedaan pedesaan dan kekhasan atau karakteristik pedesaan melalui promosi keterampilan teknis universal dan modernisasi infrastruktur fisik, bawah ke atas. Pengembangan melihat tantangan utama sebagai memanfaatkan selisih melalui memelihara khas lokal kapasitas manusia dan lingkungan itu.

Model bottom-up terutama menyangkut mobilisasi sumber daya lokal dan aset. Artinya, masyarakat pembangunan harus dianggap bukan sebagai teori pembangunan, tetapi praktek pembangunan yang menekankan emansipasi dari lembaga yang tidak pantas dan setiap melemahkan situasi yang mengarah pada perias partisipasi, pengembangan masyarakat harus menjadi mekanisme untuk menarik kekuatan kolektif anggota masyarakat tertentu yang terdiri dari laki-laki dan perempuan, kaya dan miskin, mampu dan cacat, serta yang lain-lainya untuk mengubah di wilayah mereka. Pemberdayaan ini memiliki tujuan dua arah, yaitu melepaskan belenggu kemiskinan dan keterbelakangan dan memperkuat posisi lapisan masyarakat dalam struktur kekuasaan.

Pemberdayaan adalah sebuah proses dan tujuan. Sebagai proses, pemberdayaan adalah serangkaian kegiatan untuk memperkuat kekuasaan atau keberdayaan kelompok lemah dalam masyarakat, termasuk individu-individu yang mengalami masalah kemiskinan. Sebagai tujuan, maka pemberdayaan merujuk pada keadaan atau hasil yang ingin dicapai oleh sebuah perubahan sosial; yaitu masyarakat yang berdaya, memiliki kekuasaan atau mempunyai pengetahuan dan kemampuan dalam memenuhi kebutuhan hidupnya baik yang bersifat fisik, ekonomi maupun sosial seperti memiliki kepecayaan diri, mampu menyampaikan aspirasi, mempunyai mata pencaharian, berpartisipasi dalam kegiatan sosial, dan mandiri dalam melaksanakan tugas-tugas kehidupannya (Sipahelut, 2010).

Implementasi sebagai suatu konsep tindak lanjut pelaksanaan kegiatan cukup menarik untuk dikaji oleh cabang-cabang ilmu. Hal ini semakin mendorong perkembangan konsep implementasi itu sendiri, disamping itu juga menyadari bahwa dalam mempelajari implementasi sebagai suatu konsep akan dapat memberikan kemajuan dalam upaya-upaya pencapaian tujuan yang telah diputuskan. Implementasi merupakan tahap yang sangat menentukan dalam proses kebijakan karena tanpa implementasi yang efektif maka keputusan pembuat kebijakan tidak akan berhasil dilaksanakan.
Implementasi kebijakan merupakan aktifitas yang terlihat setelah adanya pengarahan yang sah dari satu kebijakan yang meliputi upaya mengelola input untuk menghasilkan implementasi baru akan dimulai apabila tujuan dan sasaran telah ditetapkan, kemudian program kegiatan telah tersusun dan dana telah siap untuk proses pelaksanaannya dan telah disalurkan untuk mencapai sasaran atau tujuan kebijakan yang diinginkan. Pandangan Lester dan Stewart (Kusumanegara,2010) bahwa dalam proses implementasi perlu beberapa tahapan atau alur proses yang didalamnya tercakup keterlibatan berbagai macam aktor, organisasi, prosedur agar kebijakan yang telah ditetapkan mempunyai akibat, yaitu tercapainya tujuan.

Kebijakan biasanya berisi suatu program untuk mencapai tujuan, nilai-nilai yang dilakukan melalui tindakan-tindakan yang terarah. Apabila program/kebijakan sudah dibuat maka program tersebut harus dilakukan oleh para aparat kepentingan. Suatu kebijakan yang telah dirumuskan tentunya memiliki tujuan-tujuan atau target yang ingin dicapai. Implementasi sebagai suatu proses tindakan administrasi dan politik. Pandangan ini sejalan dengan pendapat Peter S. Cleaves dalam (Wahab, 2008:187), yang yang menyatakan bahwa implementasi itu mencakup " $a$ process of moving toward a policy objective by means of administrative an political steps". Secara garis besar, implementasi itu ialah Proses bergerak menuju tujuan kebijakan melalui langkah-langkah administratif dan politik. Hal tersebut ditujukan untuk membentuk suatu hubungan yang memungkinkan tujuan-tujuan ataupun sasaran-sasaran kebijakan publik diwujudkan sebagai outcome hasil akhir kegiatan yang dilakukan pemerintah.

Secara etimologis, istilah policy (kebijakan) berasal dari bahasa yunani, Sansekerta, dan Latin. Akar kata dalam Bahasa Yunani dan Sansekerta polis (negarakota) dan pur (kota) dikembangkan dalam bahasa latin menjadi politia (negara) dan akhirnya dalam bahasa inggris disebut policie, yang berarti menangani masalahmasalah publik atau administrasi pemerintahan. James E. Anderson (Sudiyono, 2007) menyebutkan bahwa kebijakan adalah serangkaian tindakan yang memiliki tujuan yang diikuti oleh seseorang atau sekelompok pelaku terkait dengan suatu permasalahan tertentu. Selanjutnya menurut Ealau dan Pewitt (dalam Suharto, 2008), kebijakan adalah sebuah ketetapan yang berlaku, dicirikan oleh perilaku yang konsisten dan berulang baik dari yang membuat atau yang melaksanakan kebijakan tersebut. Sedangkan Titmuss (dalam Suharto, 2008), mengatakan bahwa kebijakan adalah prinsip-prinsip yang mengatur tindakan dan diarahkan pada tujuan tertentu. Kebijakan adalah suatu ketetapan yang memuat prinsip-prinsip untuk mengarahkan cara bertindak yang dibuat secara terencana dan konsisten untuk mencapai tujuan tertentu. 
Dalam suatu negara atau wilayah akan memiliki suatu kebijakan yang berbeda beda dalam menangani permasalahan pemberdayaan ekonomi masyarakatnya sesuai dengan karakteristik dari masyarakat suatu daerah tersebut. Seperti halnya daerah Sumbawa Barat yang sebagian besar wilayahnya dikelilingi laut, tentu saja pemberian kebijakanya berbeda dengan yang sebafian vesar wilayahnya daratan. Sumbawa Barat terkenal akan pembudidayaan rumput laut yang terkenal dengan kualitas yang bagus dan tinggi akan jumlah permintaan rumput lautnya untuk di ekspor terutama Warga Desa Labuhan Kertasari yang sudah mulai membudidayakan rumput laut sejak dua puluh tahun yang lalu. Mayoritas warga Kertasari adalah pendatang keturunan Makasar atau Bugis yang sudah lama menetap disana sehingga mereka memiliki kebudayaan mata pencarian yang erat dengan laut salah satunya yakni budidaya Rumput Laut. Budidaya rumput laut sudah menjadi Rutinitas warga Kertasari dalam memenuhi kebutuhan hidupnya dan sebagai penghasilan tambahan mereka selain bercocok tanam. Biasanya jenis rumput laut ini dimanfaatkan untuk bahan baku kosmetik, obat-obatan dan makanan.

Dinas Kelautan dan Perikanan Kabupaten Sumbawa Barat sendiri menyiapkan program unggulan untuk menopang Visi dan Misi dari pemerintahan setempat. Salah satu program yang dicanangkan oleh pemerintah setenpat adalah program pemberdayaan ekonomi masyarakat pesisir terutama program pemberdayaan ekonomi masyarakat petani rumput laut dalam optimalisasi pengelolaan dan pemasaran produksi rumput laut. Program-program ini juga merupakan program aplikatif untuk wilayah kecamatan maupun desa/kelurahan. Namun selain program dari Dinas Kelautan dan Perikanan disejumlah kecamatan di Kabupaten Sumbawa Barat juga telah turun program yang berkaitan dengan kelautan dan perikanan. Penelitian ini akan memfokuskan pada Program Pemberdayaan ekonomi masyarakat pesisir terutama masyarakat petani rumput laut di Desa Labuhan Kertasari, menjadi kajian yang sangat menarik karena program tersebut yang terlihat nyata untuk pemberdayaan suatu masyarakat dan program tersebut dapat dirasakan masyarakat terutama masyarakat perani rumput laut. Dengan adanya kegiatan penyediaan sarana dan prasarana untuk masyarakat ini kiranya bisa mengembangkan tempat mata pencaharian masyarakat petani rumput laut. Kenyataan yang ada di lapangan penyediaan sarana dan prasarana untuk masyarakat tersebut belum sepenuhnya merata. Melihat perkembangan setiap tahunnya program ini berjalan, implementasi suatu kebijakannya terdapat permasalahanpermasalahan yaitu, belum adanya peta kawasan pengembangan tata ruang yang ditunjang oleh daya dukung lingkungan merupakan masalah dalam pengembangan pembudidayaan yang optimal dan berkelanjutan. Disamping itu secara umum masih dihadapkan beberapa permasalahan kesenjangan informasi masyarakat utamanya kesenjangan informasi pasar, informasi teknologi, dan sumber permodalan. Sehingga secara rinci permasalahan dalam pemberdayaan perekonomian masyarakat petani rumput laut meliputi pembibitan, masalah hama dan penyakit, masalah penanganan pasca panen rumput laut, pemasaran, permodalan, sumber daya manusia, permasalahan tata ruang dan permasalahan keamanan dalam mengoptimalkan pengelolaan dan pemasaran produksi rumput laut di Desa Labuhan Kertasari Kabupaten Sumbawa Barat.

Indikator-indikator

ditetapkan dalam implementasi kebijakan program pemberdayaan ekonomi masyarakat sebagai tolok ukur kesuksesan program yang disusun, sehingga ketika sebuah program pemberdayaan diberikan, segenap upaya dapat di konsentrasikan pada aspek aspek apa saja dari sasaran perubahan masalahnya, dalam hal ini masyarakat perani rumput laut yang ada di Desa Lbuhan Kertasari. Menurut Schuler, Hashemi, dan Riley (dalam Suharto, 2005) ada beberapa indikator pemberdayaan yang disebut juga sebagai empowerment index atau indeks pemberdayaan diantaranya sebagai berikut:

1) Kebebasan mobilitas yaitu kemampuan individu untuk pergi keluar rumah atau wilayah tempat tinggalnya. Tingkat mobilitas dianggap tinggi seseorang mampu melakukan mobilitas sendirian.

2) Kemampuan membeli komoditas kecil, merupakan kemampuan individu untuk membeli barang- barang kebutuhan sehari-hari seperti sembako, kebutuhan pribadi seperti rokok dan kosmetik, dan komoditas kecil lainnya.

3) Kemampuan membeli komoditas besar, merupakan kemampuan individu untuk membeli barang- barang sekunder dan tersier

4) Terlibat dalam pembuatan keputusan-keputusan seperti mampu membuat keputusan secara sendiri maupun bersama anggota keluarga mengenai keputusan-keputusan keluarga.

5) Kebebasan relatif dan dominasi keluarga.

6) Kesadaran hukum dan politik.

7) Keterlibatan dalam kampanye ataupun unjuk rasa

8) Jaminan ekonomi dan kontribusi terhadap keluarga seperti memiliki rumah, tanah, aset produktif maupun tabungan.

Penelitian ini bertujuan untuk mengetahui implementasi kebijakan program pemberdayaan ekonomi masyarakat pesisir terutama masyarakat petani rumput laut di Desa Labuhan Kertasari Kabupaten Sumbawa Barat. Implementasi kebijakan program tersebut berupa kebijakan dalam berkomunikasi antara pihak terkait dengan pemangku kebijakan, sumberdaya, disposisi atau sikap yang terlihat dari pembuat kebijakan dan struktur birokrasi yang diterapkan oleh daerah setempat. 


\section{METODE}

George Edward III (Leo Agustino (2006) mengungkapkan bahwa terdapat empat Faktor yang sangat menentukan keberhasilan implementasi suatu kebijakan. Dinyatakan dengan tegas bahwa tanpa implementasi yang efektif, keputusan pembuat kebijakan tidak akan berhasil dilakukan. Oleh karenanya, Edward III menyarankan untuk memberikan perhatian kepada empat isu utama: komunikasi, sumber daya, disposisi dan struktur birokrasi. Seperti yang tertera pada gambar berikut:

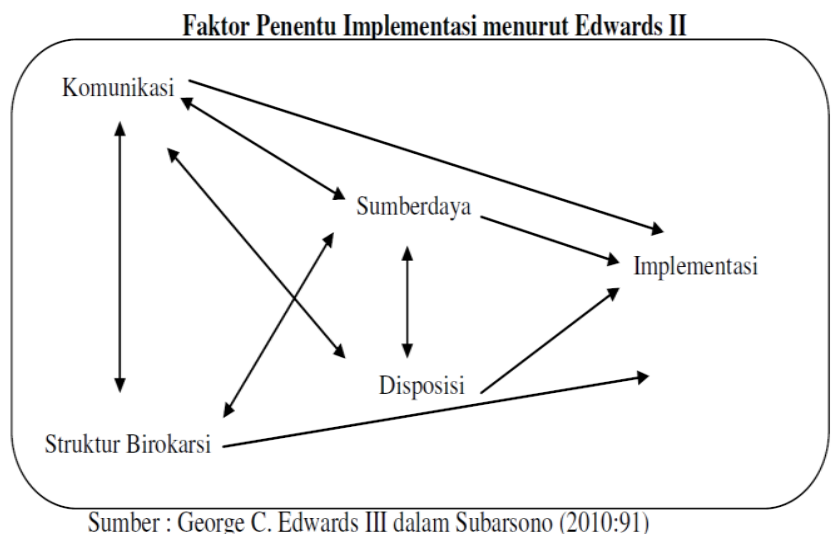

Gambar 1. Faktor Penentu Implementasi menurut Edwars II

Jenis penelitian yang sesuai digunakan untuk mengetahui implementasi kebijakan program pemberdayaan ekonomi di Desa Labuhan Kertasari Kabupaten Sumbawa barat mengenai komunikasi, sumberdaya, desposisi, dan struktur birokrasinya adalah penelitian kualitatif deskriptif, dimana data yang dikumpulkan berbentuk kata-kata, gambar, bukan angkaangka. Menurut Bogdan dan Taylor (dalam Moleong, 2008) menjelaskan tentang penelitian kualitatif adalah prosedur penelitian yang menghasilkan data deskriptif berupa kata-kata tertulis atau lisan dari orang-orang dan perilaku yang diamati.

Lokasi penelitian berada di daerah pesisir Desa Labuhan Kertasari Kabupaten Sumbawa Barat, dimana yang menjadi key informan dari penelitian ini adalah petani rumput laut sebanyak 5 orang. Keabsahan data dalam penelitian ini ditentukan dengan menggunakan kriteria kredibilitas. Untuk mendapatkan data yang relevan, maka peneliti melakukan pengecekan keabsahan data hasil penelitian seperti yang dikemukakan oleh Sugiyono (2012) dengan cara: 1) perpanjangan pengamatan, 2) ketekunan pengamatan dan 3) triangulasi sumber. Adapun model analisis data dalam penelitian ini mengikuti konsep yang diberikan Miles and Hubermen (2014) yang mengungkapkan bahwa aktifitas dalam analisis data kualitatif dilakukan secara interaktif dan berlangsung secara terus-menerus pada setiap tahapan penelitian hingga tuntas. Untuk mencapai tujuan penelitian yang diharapkan, maka data yang dikumpulkan dianalisis secara kualitatif baik data primer maupun data sekunder, dengan melakukan tiga alur kegiatan (triangulasi) yaitu: reduksi data, penyajian data, verivikasi atau penyimpulan data.

\section{HASIL DAN PEMBAHASAN Ketepatan Kebijakan}

Desa Labuhan Kertasari sudah lama dikenal dengan budidaya rumput lautnya. Petaninya pun merupakan warga desa tersebut yang sebelumnya lama bekerja sebagai petani jagung dan berbagai pekerjaan lainnya. Hasil di lapangan setelah melakukan wawancara mendalam dengan para petani rumput laut dan pemangku kebijakan dalam hal ini pemerintah setempat ditemukan suatu kendala dalam hal berkomunikasi antara para petani rumput laut dan pemerintahan setempat. Hal tersebut dikarenakan karena para petani rumput laut kurang mengetahui adanya program untuk pemberdayaan ekonomi masyarakat serta pemerintah setempat sudah melakukan sosialisasi namun sasarannya belum menyeluruh menyentuh kepada para petani rumput laut. Seperti yang dikemukakan oleh informan IA berikut:

"saya menekuni untuk menjadi petani rumput laut ini baru, karena saya dulu menekuni pertanian jagung jadi saya belum tau pasti ada program seperti itu, ya....saya ikuti saja semampu dan sepengetahuan saya dalam membudidayaakan rumput laut ini."

Ketidak tauhan petani akan adanya program pemberdayaan ekonomi yang dilakukan pemerintah setempat membuat kendala tersendiri bagi para petani rumput laut karena dalam proses tanam sampai panen rumput laut tentu memiliki kendala seperti pembibitan, cuaca, hama, pemasaran,dan lain sebagainya. Budidaya rumput laut sudah menjadi aktivitas rutin sehari-hari warga Desa Labuhan Kertasari untuk memenuhi segala kebutuhan rumah tangganya sebagai penghasilan utama. Para petani menetapkan rata-rata siklus masa tanam rumput laut satu hingga satu setengah bulan dan dalam setahun para petani bisa panen sekitar 8 kali. Akan tetapi ada kurun waktu dimana para petani tidak menanam rumput laut yakni saat musim hujan. Komunikasi disini sangat perlu dilakukan pada pemerintah setempat untuk menetapan suatu kebijakan dalam mengatasi permasalahan petani rumput laut pada saat musim kemarau tiba.

Pada implementasinya Program Pemberdayaan Ekonomi Masyrakat petani rumput laut yang ada di Desa Labuhan Kertasari sudah tepat, namun masih ada beberapa petani rumput laut yang baru menggeluti usaha budidaya pertanian rumput laut belum mengetahui program yang sudah ada tersebut. Maka perlunya komunikasi antara petani dengan pemerintah setempat sehingga para petani baik baru ataupun yang lama bisa merasakan manfaat dari adanya program tersebut. Karena dengan adanya program tersebut dapat meningkatkan perekonomian para petani rumput laut. 
Seperti kegiatan penanaman bibit rumput laut, cara pemeliharaan tanaman rumput laut baik saat musim penghujan, kemarau ataupun pancaroba, cara menghadapi hama tanaman, proses pemanenan rumput laut yang baik sehingga menghasilkan kualitas baik, serta strategi pemasaran untuk memasarkan hasil panen tanaman rumput laut tersebut. Dimana dengan tanaman rumput laut bisa dijadikan berbagai macam olahan produk yang memilki nilai ekonomi tinggi sehingga dapat meningkatkan pendapatan atau perekonomian petani rumput laut.

Pada kenyataanya di lapangan ada terdapat beberapa kegiatan dari Program Pemberdayaan Ekonomi Masyarakat petani rumput laut tersebut tidak berjalan sesuai dengan yang diharapkan. Misalnya dalam Pembagian zonasi untuk tanaman rumput laut di pantai kepada para petani rumput laut. Hal ini disebabkan karena salah satunya adalah struktur birokrasi yang dimiliki pemerintah setempat belum mempunya Standar Operasional Prosedur (SOP) yang julas untuk mebagi zonasi kepemilikan bagi para petani rumput laut. Oleh karena itu agar kegiatan ini dapat berjalan secara maksimal Dinas Kelautan dan Perikanan Kabupaten Sumbawa Barat hendaknya memiliki SOP yang jelas agar sumberdaya yang dimilki bisa dikelola dengan baik.

\section{Ketepatan Pelaksanaan}

Keefektifan atau tidaknya Program Pemberdayaan Ekonomi Masyarakat petani rumput laut yang dilaksanakan di Desa Labuhan Kertasari Kabupaten Sumbawa Barat yang dilakukan oleh pemerintah setempat atau pihak yang terlibat dalam proses penanganan program tersebut sudah dikatakan tepat sasaran. Hal ini bisa dilihat dari keseriusan dan keberlanjutan pihak pemerintah setempat melalui Dinas Kelautan dan Perikanan Kabupaten Sumbawa Barat sudah melaksanakan kegiatan tersebut secara terprogram setiap tahunnya. Seperti yang dikemuakam oleh informan kunci berinisial AYA ketika dilakukan wawancara mendalam berikut:

"kalau bantuan dari pemerintah ada tentang pemberian bibit, dan kami diarahkan untuk membuat kelompok tani rumput laut untuk diberikan pelatihan pembudidayaan rumput laut yang berkualitas dan itu sudah berjalan beberapa tahun ini, dan ya.... bersyukur dengan adanya program ini, namun yang dapat pelatihan itu itu saja".

Dari penuturan AYA tersebut jelaslah bahwa kegiatan pelaksanaan dari program pemberdayaan ekonomi masyarakat petani rumput laut sudah tepat sasaran, namun terdapat beberapa kekurangan dalam hal pengimplementasian Program Pemberdayaan Ekonomi Masyarakat petani rumput laut ini pihak Desa Labuhan Kertasari kurang ikut berperan dalam pelaksanaan program tersebut. Pihak kelurahan Desa Labuhan
Kertasari hanya ikut andil dalam program ini sebatas memfasilitasi saja tanpa ikut terlibat langsung dalam pelaksanaan program tersebut. Ada beberapa faktor yang mempengaruhi pihak kelurahan Desa Labuhan Kertasari tidak terlibat langsung dalam program tersebut diantaranya adalah faktor sumberdaya manusia yang mumpuni dalam bidang pertanian rumput laut, disposisi atau sikap yang terlihat dari pembuat kebijakan untuk merangkul pihak kelurahan dalam pembudidayaan rumput laut dan tidak adanya informasi mengenai tata cara pelaksanaan. Dengan tidak adanya tata cara pelaksanaan ini membuat pihak kelurahan hanya mengikuti perintah atau himbauan dari dinas tanpa tahu harus melakukan apa pada Program Pemberdayaan Ekonomi Masyarakat Petani Rumput Laut ini.

\section{Ketepatan Lingkungan}

Dalam Pengimplementasian Program

Pemberdayaan Ekonomi Masyarakat Petani Rumput laut sudah tepat bagi masyarakat setempat, hal ini dikarenakan banyak kegiatan-kegiatan yang terdapat di dalam program tersebut sudah bisa memperoleh peningkatkan kemampuan perekonomian masyarakat setempat. Seperti pemberian bantuan kepada kelompok masyarakat untuk dikembangkan sehingga dengan bantuan tersebut masyarakat mampu meningkatkan kemampuan perekonomianya. Namun, terlepas dari itu terdapat suatu hambatan yang dihadapi pada saat pelaksaan Program Pemberdayaan Ekonomi Masyarakat Petani Rumput Laut tersebut, dimana menurut hasil wawancara informan didapatkan bahwa ada beberapa kelompok masyarakat yang menyimpang dengan menyalahgunakan pemberian bantuan yang telah diberikan untuk dijual oleh kelompok tersebut. Seperti yang dituturkan oleh informan MRD berikut:

"kadang masyarakat sini bisa dibilang ada bandelnya juga apalagi setelah dibentuk kelompok tani rumput laut....mendapat bantuan bibit dan tali ris,pelatihan juga. Mereka yang dapat bantuan tidak semuanya jadi kadang tidak tepat sasaran, karena yang tidak tanam kadang dapat bibit. Yang ikut pelatihan juga itu-itu saja dan tidak pernah dipraktikkan lagi, selain juga tidak tahu jualnya ke mana"

Permasalahan yang dituturkan oleh informan tersebut tentu tidak lepas dari faktor-faktor yang mempengaruhinya, sehingga ada saja kelompok tani rumput laut yang bandel. Hal tersebut bisa dilihat dari struktur birokrasinya dimana dalam menjalankan tugastugas dalam pengambilan keputusan harus mengikuti rantaian komando sehingga ada yang melihat permasalahan tersebut membutuhkan proses yang lama untuk ditinjak lanjuti. Selain struktur birokrasi, pengawasan yang dilakukan oleh Dinas Kelautan dan Perikanan Kabupaten Sumbawa Barat terhadap adanya 
program ini dirasakan kurang efektif. Hal ini dikarenakan setelah melaksanakan program tersebut tidak ditindak lanjuti kembali dengan pemantauan atau pengawasan kembali kepada masing-masing kelompok tani rumput laut.

Untuk pengawasan pada Program Pemberdayaan Ekonomi Masyarakat Petani Rumput Laut, Dinas Kelautan dan Perikanan Kabupaten Sumbawa Barat hanya 3 sampai 4 kali dalam kurun waktu setahun melakukan pengawasan tersebut. Tentu saja ini sangat kurang sehingga timbul permasalahan yang telah diungkapkan informan MRD ini. Seharusnya pengawasan yang dilakukan oleh Dinas Kelautan dan Perikanan Kabupaten Sumbawa Barat terhadap Program Pemberdayaan Ekonomi Masyarakat Petani Rumput Laut dilakukan setiap bulan sehingga Dinas Kelautan dan Perikanan Kabupaten Sumbawa Barat bisa mengetahui perkembangan dari bantuan yang mereka berikan dalam rangka melaksanakan program pemberdayaan tersebut.

\section{Ketepatan Target}

Salah satu indikator efektif dari implementasi Program Pemberdayaan Ekonomi Masyarakat Petani Rumput Laut adalah dengan melihat dari sudut pandang dalam menentukan ketepatan target, dimana dalam hal ini mampu menangani laju tingkat kemiskinan yang terdapat di wilayah pesisir Desa Labuhan Kertasari yang semakin lama meningkat. Dilihat dari hasil penelitian dilapangan dimana kegiatan dalam program ini harus dilakukan untuk demi meningkatkan kemampuan perekonomian masyarakat yang ada di wilayah Kabupaten Sumbawa Barat Salah sarunya Desa Labuhan Kertasari. Pada implementasi Program Pemberdayaan Ekonomi Masyarakat Petani Rumput Laut tersebut sudah sesuai dengan target. Seperti yang telah dikemukakan oleh informan ACO berikut:

\section{"Sasaran yang dilakukan oleh pihak terkait sebenarnya sudah tepat dengan memberikan bantuan bibit rumput laut sampai dengan proses panen untuk memberdayakan rumput laut tersebut, karena potensi di desa kita ini sumber dayanya ya....untuk rumput laut selain peperkebunan kelapa dan jagung ”}

Apa yang dituturkan ACO tersebut hampir sama apa yang ditemukan dilapangan dengan kondisi sumber daya alam yang dimilki Desa Labuhan Kertasari yang berada diwilayah pesisir. Ini dapat dilihat dari kegiatankegiatan yang berbasis pada masyarakat, seperti perkebunan dan pemberian bantuan bibit unggul kepada para petani rumput laut dan kepada kelompok masyarakat petani rumput laut di Desa Labuhan Kertasari. Sudah sesuainya target dalam pelaksanaan Program Pemberdayaan Ekonomi Masyarakat Petani Rumput Laut tentu saja dipengaruhi beberapa faktorfaktor yang mendukung. Salah satu pendukungnya adalah faktor komunikasi yang selaras yang didapat dari data-data mengenai jumlah petani rumput laut di tingkat Desa Labuhan Kertasari Kabupaten Sumbawa Barat. Selain itu juga sumber daya yang terdapat di daerah Desa Labuhan Kertasari tersebut yang memungkinan dilakuannya pemberdayaan rumput laut sebagai bagian dari gerakan perekonomian menuju perekonomian mandiri, dengan mengolah hasil panen rumput laut menjadi produk yang berkualitas. Adanya tehonoli pengolahan secara tidak langsung akan berdampak pada tingkat pendapatan masyarakat akan meningkat menjadi lebih baik. Peningkatan pendapatan, dimungkinkan akan menjadi faktor peningkatan kesejahteraan masyarakat Desa Labuhan Kertasari khususnya dan Kabupaten Sumbawa Barat umumnya.

\section{Ketepatan Proses}

Pada implementasinya Program Pemberdayaan Ekonomi Masyarakat Petani Rumput Laut sudah sesuai dengan proses yang ditentukan seperti pemberian bantuan kepada kelompok masyarakat. Namun, kendala yang dihadapi Dinas Kelautan dan Perikanan Kabupaten Sumbawa Barat dalam melaksanakan Program Pemberdayaan Ekonomi Masyarakat yersebut adalah dengan melonjaknya permintaan masyarakat untuk menekuni pembudidayaan rumput laut membuat bantuan yang diberikan tidak sesuai dengan standar yang ditetapkan oleh Dinas Kelautan dan Perikanan Kabupaten Sumbawa Barat. Kendala ini tentu saja tidak lepas dari beberapa faktor yang mempengaruhinya, salah satunya permodalan. Dimana sumber daya anggaran dana yang dimiliki oleh Dinas Kelautan dan Perikanan Kabupaten Sumbawa Barat dalam melaksanakan Program Pemberdayaan Ekonomi Masyarakat Petani Rumput Laut yang ada di Desa Labuhan Kertasari dana yang dianggarkan masih dirasa kurang. Dana yang dianggarkan oleh Dinas tidak sebanding dengan banyaknya masyarakat yang harus diberdayakan sehingga tidak semua masyarakat mendapatkan bantuan. Mengatasi hal tersebut Dinas Kelautan dan Perikanan Kabupaten Sumbawa Barat akan memberikan bantuan kepada kelompok masyarakat secara bertahap dengan tujuan agar kualitas dan kuantitas bantuan yang diberikan kepada masyarakat sesuai dengan standar yang diinginkan oleh Dinas Kelautan dan Perikanan Kabupaten Sumbawa Barat.

\section{SIMPULAN}

Dari paparan hasil dan pembahasan yang telah dilakukan sebelumnya bahwa Program Pemberdayaan Ekonomi Masyarakat Petani Rumput Laut di Desa Labuhan Kertasari Kabupaten Sumbawa Barat ini sudah berjalan dengan baik namun ada beberapa hal yang masih menjadi kendala dalam pelaksanaan program tersebut dimana masih belum berjalannya beberapa kegiatan seperti Pembagian zonasi untuk tanaman rumput laut di pantai kepada para petani rumput laut 
sesuai dengan potensi hamparan pantai yang layak untuk dijadikan tempat pembudidayaan rumput laut. Selain itu Tidak adanya Standar Operasional Prosedur (SOP) yang jelas sehinnga program ini tidak berjalan secara maksimal. Masih kurangnya koordinasi dan komunikasi yang intens antara pihak Dinas Kelautan dan Perikanan Kabupaten Sumbawa Barat dengan pihak Desa Labuhan Kertasari. Masih kurangnya petugas yang melakukan pengawasan dalam pelaksanaan program tersebut.

Adapun saran atau rekomendasi yang dapat diberikan dari penelitian ini berupa langkah-langkah yang mungkin diambil untuk mencapai kesuksesan dalam mengadakan Program Pemberdayaan Ekonomi Masyarakat Petani Rumput Laut di Desa Labuhan Kertasari Kabupaten Sumbawa Barat sebagai berikut:

1) Dinas Kelautan dan Perikanan Kabupaten Sumbawa Barat hendaknya harus mempunyai Standar Operasional Prosedur (SOP) yang jelas dan akurat mengenai Program Pemberdayaan Ekonomi Masyarakat Petani Rumput Laut sehingga dengan demikian program tersebut bisa berjalan dengan maksimal dan sesuai dengan standar yang ditentukan.

2) Untuk konsistensi pengawasan yang diberikan Dinas Kelautan dan Perikanan Kabupaten Sumbawa Barat harus harus melakukan pengawasan terhadap program tersebut secara konsistensi setidaknya dalam 1 bulan ada 3 kali melakukan pengawasan atau paling sedikit setiap bulan melakukan pengawasan sehingga perkembangan program tersebut dapat diketahui keberhasilanya.

3) Untuk kerjasama dan koordinasi sebaiknya pihak Desa Labuhan Kertasari dilibatkan dalam setiap pembuatan program yang akan dilakukan didaerahnya.

4) Untuk mengatasi kekurangan sumber daya keuangan Dinas Kelautan dan Perikanan Kabupaten Sumbawa Barat harus memberikan secara bertahap bantuan kepada kelompok masyarakat.

\section{DAFTAR PUSTAKA}

Agustino, L. 2006. Dasar-Dasar Kebijakan Publik. Bandung: CV. Alfabeta

Kusumanegara, Solahuddin. 2010. Model Dan Aktor Dalam Proses Kebijakan Publik. Edisi Pertama. Yogyakarta: Gava Media,

Lexy J. Moleong. 2008. Metodologi Penelitian Kualitatif Edisi Revisi. Bandung: Remaja Rosdakarya

Miles dan Hubermen. 2014. Analisis data kualitatif. Jakarta: Universitas Indonesia.

Peraturan Mentri Kelautan dan Perikanan Republik Indonesia nomor 40/Permen-KP/2014 tentang peran serta dan pemberdayaan masyarakat dalam pengeloaan wilayah pesisir dan pulau-pulau kecil.

Sipahelut, M. 2010. Analisis Pemberdayaan Masyarakat Nelayan Di Kecamatan Tobelo Kabupaten Halmahera Utara. Universitas Institut Pertanian Bogor
Subarsonon, AG. 2010. Analisis Kebijakan Publik Konsep Teori dan Aplikasi. Yogyakarta Pustaka Pelajar.

Sudiyono.2007. Dari Formulasi Ke Implementasi Kebijakan Pendidikan. Buku Ajar

Sugiyono.2012. Metode Penelitian Pendidikan Pendekatan Kuantitatif, Kualitatif, dan $R \& D$. Bandung: Alfabeta

Suharto, Edi. 2005. Membangun Masyarakat Memberdayakan Rakyat. Bandung:Refika Aditama

Suharto, Edi. 2008. Kebijakan Sosial Sebagai Kebijakan Publik.Bandung: Alfabeta

Suharto, Edi. 2010. Membangun Masyarakat Memberdayakan Rakyat. Bandung: Refika Aditama

Shucksmith, Mark. 2013. Future Direction in Rural Development. Cernegie UK Trust, England

Wahab, Solichin A. W. 2008. Analisi Kebijaksanaan Dari Formulasi Ke Implementasi Kebijaksanaan Negara. Edisi Kedua. Jakarta: PT.Bumi Aksara 